Jurnal Pena Sains Vol. 6, No. 1, April 2019

p-ISSN: 2407-2311

e-ISSN: 2527-7634

\title{
TEACHER SKILLS IN DEVELOPING INSTRUMENTS OF TEST ESSAY IN SCIENCE LESSONS IN JUNIOR HIGH SCHOOL: Case Study Kediri, East Java-Indonesia
}

\author{
Laily Rosdiana $^{1}$, Martini ${ }^{2}$, Aris Rudi Purnomo ${ }^{3}$, An Nuril Maulida Fauziah ${ }^{4}$ \\ ${ }^{1}$ Program Studi Pendidikan Sains, FMIPA, Universitas Negeri Surabaya, 60231 , Indonesia \\ lailyrosdiana@unesa.ac.id
}

Accepted: October 30, 2018

Published: April 30, 2019

DOI: $\underline{\text { http://doi.org/10.21107/ips.v6i1.5248 }}$

\begin{abstract}
Assessment and evaluation must always be carried out. The evaluation process is one of the teacher's tasks that will determine the direction of the next learning process. Therefore, the teacher must be skilled in compiling the question test instrument, one of which is a matter of description. Regarding this objective, teachers need to be equipped with ways to prepare these instruments so that the quality of the questions made meets the standards and by the indicators of learning. Briefing on the science teachers MGMPs Kediri shows that teachers already have skills in preparing the description of the test instrument with a percentage of $53.12 \%$ about the level and $46.88 \%$ HOTS LOTS level. Based on the results, the skills of science teachers in Kediri District are not expectations. The teachers must continue to practice in making the test instruments.
\end{abstract}

Keywords: essay, skill, test instrument

\footnotetext{
${ }^{1}$ Corresponding Author
} 


\section{Introduction}

Based on Law No. 20 of 2003 which discusses the National Education System shows that education is a conscious and planned effort to create a learning atmosphere and learning process so that students actively develop their potential to have religious, spiritual strength, self-control, personality, intelligence, noble character, and the necessary skills himself, society, nation, and country. Based on the understanding of education there are several essential things from the concept of education, one of which is a planned educational process that directed at realizing the learning atmosphere and the learning process. That shows that education must pay attention to the processes that occur during learning and not only focus on learning outcomes, so that learning processes and outcomes must be balanced (Sanjaya, 2008). Natsir (2007) stated that the low quality of Indonesian education shown from 146,052 elementary schools in Indonesia. It turned out that only eight schools received world recognition in the Primary Years Program (PYP) category. Of the 20,918 junior high schools in Indonesia, it turned out that only eight worldrecognized schools in the Middle Years Program (MYP) category and of the 8036 high schools it turned out that only seven schools recognized in the category of the Diploma Program (DP).

Various efforts have been made by the government to improve the quality of education in Indonesia. One of them is by updating the education curriculum in Indonesia. The curriculum is a set of plans and arrangements regarding the purpose, content, and material of learning and the methods used as guidelines for the implementation of learning activities to achieve specific educational goals (Sisdiknas, 2003). The curriculum is one of the factors supporting the success of education, besides there are other factors that also have important roles such as; HR, facilities and infrastructure, political, social, economic and cultural situations (Winarno, 2012).

The evaluation process is one of the teacher's tasks that will determine the direction of the next learning process. According to Ratumanan (2003), evaluation can be expressed as a systematic process in determining the level of achievement of instructional goals. Meanwhile, Winarno (2004) states that evaluation is a systematic process for determining values based on data collected through measurements. The process of value taking must be done objectively, and subjective elements sought not included as consideration and judgment. The evaluation process is carried out after the design process. In this process, a decision-making process made on the results of the assessment that has been carried out. In other words, it can be stated that evaluation includes the three steps ahead, namely measuring, evaluating and giving decisions. Furthermore, this process cannot be carried out without measurement and assessment activities.

According to Presseisen (Devi, 2011) states that HOTS (High Order Thinking Skills) or high-level thinking skills divided into four groups, namely problem solving, making decisions, critical thinking and creative thinking. The process that is more emphasized is in critical thinking groups. Critical thinking is one of the complex thinking processes under creative thinking. Critical thinking is an activity of thinking deeply about various things to conclude. This is in line with the opinion of Ennis (Tilaar, 2011) stating that critical thinking is a reflective thinking process that focuses on deciding what is believed to be done. 
In general, the purpose of critical thinking is to test a statement, opinion or idea, an idea. According to Ennis (Tilaar, 2011) suggests that indicators of critical thinking skills divided into five groups, namely providing simple explanations, building basic skills, concluding, making further explanations and regulating strategies and tactics. Critical thinking is a cognitive skill and intellectual disposition that is needed effectively. Furthermore, Bassham (Sulistiono et al, 2014) says that the purpose of critical thinking is first, to identify, analyze, and evaluate arguments and truths. Second, to find and overcome personal prejudice and bias. Third to formulate and provide convincing reasons. Finally, to support conclusions, and make reasonable decisions about what to believe and what to do. This shows the importance of teaching students thinking skills and how to measure students' critical thinking skills to teachers.

Based on the situation analysis and review of several books related to the demands of Law No. 20 of 2003 relating to a planned educational process that is directed at realizing the learning atmosphere and the learning process. This shows that in education must pay attention to the processes that occur during learning and not only focus on learning outcomes, so that the learning process and results must be balanced, so debriefing of teachers is needed so that they have the skills in making the Description Problem Test Instrument that meets standards and according to the indicator of learning.

\section{Research Method}

The type of research used in this study is Pre-Experimental Design with sample selection by purposive sampling (Sugiyono, 2015). The study design in this study used One-Shot Case Study. This research was conducted in the even semester of the 2017/2018 academic year at SMP Negeri 1 Grogol with the research subject of Science teachers on Kediri District. The stages of the research carried out begin with the provision of theory, workshops, and data analysis of the results of the preparation of Instruments Tests for essay questions.

\section{Result and Discussion}

The results achieved at the beginning of the implementation of the activity is to provide theories related to the preparation of question instruments, namely by providing material that the preparation of questions must be in accordance with learning indicators, and the items must be HOTS level, and provide examples of how to make questions complete with standard instruments.

At the stage of the workshop, the teachers are required to carry out all the activities that are already in the Activity Sheet that are distributed, including writing Basic Competencies (BC), learning indicators that are following $\mathrm{BC}$, HOTS level questions and test instruments. After mentoring activities for making essay test instruments, data obtained in table 1 . 


\section{Rosdiana, Martini, Purnomo, Fauziah}

Table 1. Result of Analysis HOTS Test

\begin{tabular}{|c|c|c|c|c|c|c|c|c|}
\hline \multirow[b]{2}{*}{ Group } & \multirow[b]{2}{*}{$\begin{array}{c}\text { Number of } \\
\text { Tests }\end{array}$} & \multicolumn{5}{|c|}{ Indicator of Critical Thinking Skills } & \multicolumn{2}{|c|}{ Level of Test } \\
\hline & & $\begin{array}{c}\text { Simple } \\
\text { Explanation }\end{array}$ & $\begin{array}{l}\text { Develop of } \\
\text { Basic Skills }\end{array}$ & Concluding & $\begin{array}{l}\text { Making further } \\
\text { explanations }\end{array}$ & $\begin{array}{c}\text { Regulating } \\
\text { strategies } \\
\text { and tactics }\end{array}$ & HOTS & LOTS \\
\hline \multirow[t]{3}{*}{1} & & 2 & 2 & 1 & 2 & 1 & & \\
\hline & 8 & $\mathrm{H}=2$ & $\mathrm{H}=0$ & $\mathrm{H}=0$ & $\mathrm{H}=0$ & $\mathrm{H}=0$ & 2 & 6 \\
\hline & & $\mathrm{L}=0$ & $\mathrm{~L}=2$ & $\mathrm{~L}=1$ & $\mathrm{~L}=2$ & $\mathrm{~L}=1$ & & \\
\hline \multirow[t]{3}{*}{2} & & 2 & 1 & 2 & 1 & 2 & & \\
\hline & 8 & $\mathrm{H}=2$ & $\mathrm{H}=0$ & $\mathrm{H}=2$ & $\mathrm{H}=0$ & $\mathrm{H}=1$ & 5 & 3 \\
\hline & & $\mathrm{L}=0$ & $\mathrm{~L}=1$ & $\mathrm{~L}=0$ & $\mathrm{~L}=1$ & $\mathrm{~L}=1$ & & \\
\hline \multirow[t]{3}{*}{3} & & 2 & 2 & 2 & 1 & 1 & & \\
\hline & 8 & $\mathrm{H}=2$ & $\mathrm{H}=0$ & $\mathrm{H}=2$ & $\mathrm{H}=1$ & $\mathrm{H}=0$ & 5 & 3 \\
\hline & & $\mathrm{L}=0$ & $\mathrm{~L}=2$ & $\mathrm{~L}=0$ & $\mathrm{~L}=0$ & $\mathrm{~L}=1$ & & \\
\hline \multirow[t]{5}{*}{4} & & 1 & 2 & 2 & 2 & 1 & & \\
\hline & 8 & $\mathrm{H}=1$ & $\mathrm{H}=1$ & $\mathrm{H}=2$ & $\mathrm{H}=1$ & $\mathrm{H}=0$ & 5 & 3 \\
\hline & & $\mathrm{L}=0$ & $\mathrm{~L}=1$ & $\mathrm{~L}=0$ & $\mathrm{~L}=1$ & $\mathrm{~L}=1$ & & \\
\hline & \multicolumn{6}{|c|}{ Total } & 17 & 15 \\
\hline & \multicolumn{6}{|c|}{ Percentage } & 53,12 & 46,88 \\
\hline
\end{tabular}

Based on table 1, the percentage of HOTS and LOTS of questions made by teachers is still deficient, because when viewed from the percentage it is not very different. Research conducted by Heong, et al. (2012) shows that the difficulty in generating ideas in making questions, students will experience technical problems in completing their tasks. That is a significant factor that influences student achievement. Therefore, teachers need to learn more about making HOTS questions to overcome difficulties in generating ideas. HOTS is essential because it can help students to complete tasks.

In table 1 shows that the teachers already have the skills in preparing test questions with the percentage of $53.12 \%$ with HOTS levels and $46.88 \%$ about LOTS levels. That indicates that the teacher's ability to arrange HOTS questions is still in the moderate category. Because there are still many teachers, who are still accustomed to developing LOTS of questions. The teacher needs a further mentoring process in developing questions that are following the HOTS indicator, especially on questions that emphasize critical thinking skills.

Based on the results of the analysis of 8 items in each group, it was found that the questions made by the teacher for HOTS criteria were mostly only on indicators of critical thinking skills, simple explanations, and conclusions, while for indicators building basic skills, making further explanations and set many strategies and tactics that fall into the 
category of LOTS. That is in line with the research of Redhana (2007), that some teachers do not understand the essence of learning critical thinking skills, very few indicators of critical thinking skills that appear in indicators of learning outcomes. Furthermore, critical thinking skills focus on the learning process so critical thinking skills are essential to be trained to students because these skills provide opportunities for students to learn through discovery.

The HOTS problem is the ability to think that tests at a higher level, in the sense that it not only tests aspects of memory or memorization, but examines the elements of analysis, synthesis, and evaluation. That shows that HOTS is an achievement of thinking ability towards higher level thinking. The purpose of higher-level thinking thinks that is more than just a repetition of facts. From the analysis above, it can be concluded that the teachers are only at the HOTS stage which is still lower level, while for the higher levels there are even less.

\section{Conclusion}

Finally, it can be concluded that the teacher who can make HOTS questions is $53.12 \%$ with indicators of critical thinking skills a simple explanation and conclusion, while the LOTS problem is $46.88 \%$. Based on the results of the analysis conducted on the questions that have been made by the teacher it can be said that the teacher's ability to make HOTS questions with the category of indicators is still low, while there are many high categories of indicators because of LOTS. Based on the results of the above conclusions, it can be suggested that teachers must practice a lot in making questions and instruments so they can make HOTS category questions with the fifth level of indicators fulfilling the eligibility criteria when tested to students, so students can answer correctly and correctly.

\section{References}

Heong, Y. M., Widad, J., Kiong, Tee Tze, Razali, M. (2011). The Level of Marzuno Higher Order Thinking Skills among Technical Education Students. International Journal of Social Science and Humanity, vol. 1, No.2.

Kamalia D. P. (2011). Pengembangan Soal "Higher Order Thinking Skill" dalam Pembelajaran IPA SMP / MTs. [Online]. Diakses dari http://p4tkipa.net/datajurnal/HOTs.Poppy.pdf

Natsir, N. F. (2007). Peningkatam Kualitas Guru dalam Perspektif Pendidikan Islam. Journal Educationist, Vol.1 (1): 2-22

Ratumanan, T.G. (2003). Pengaruh Model Pembelajaran Dan Gaya Kognitif Terhadap Hasil Belajar Matematika Siswa SLTP Di Kota Ambon. Jurnal Pendidikan Dasar, vol. 5 (1): 1-10.

Redhana, I. W. (2007). Chemistry Teachers' View Towards Teaching and Learning and Assessment of Critical Thinking Skills. Proceeding of The First International Seminar on Science Education Bandung, 2007.

Sanjaya, W. (2008). Strategi Pembelajaran; Berorientasi Standar Proses Pendidikan. Jakarta: Kencana.

Sugiyono. 2015. Metode Penelitian Kuantitatif Kualitatif dan R\&D. 
Rosdiana, Martini, Purnomo, Fauziah

Bandung: Alfabeta

Sulistiono, E., Tjandrakirana, Rahayu, S. R. (2014). Peningkatan Kemampuan Berpikir Kritis Siswa Menggunakan Perangkat Pembelajaran IPA SMP Berorientasi Penyelesaian Masalah. Jurnal Pena Sains, Vol 2 (2): 46-55

Tilaar, M., Paat, J. Ph., \& Paat, L. (2011). Pedagogik Kritis. Jakarta: Rineka Cipta

Undang-undang Sisdiknas. (2003). Pendidikan Anak Usia Dini. Jakarta : Depdiknas

Winarno, M. E. (2004). Evaluasi dalam Pendidikan Jasmani dan Olahraga. Jakarta: Center Human Capacity Development

Winarno, M. E. (2012). Metodologi Penelitian dalam Pendidikan Jasmani. Malang: Media Cakrawala Utama PressSugiyono. (2004). Statistik untuk Penelitian.Jakarta: Raja Grafindo 